\title{
Exploring the Role of Perceived Contextual and Environmental Motivators in Venture Creation: Survey in South Asian Context
}

\author{
Tariq Ahmed ${ }^{1} \&$ Ahmad Zahiruddin Bin Yahya ${ }^{2}$ \\ ${ }^{1}$ department of Management Sciences, Balochistan university of information technology, Engineering and \\ Management Sciences, Quetta, Pakistan; \\ ${ }^{2}$ Senior Lecturer Department of Accountancy, Faculty of Business and Accountancy, University of Malaya, 50603 \\ Kuala Lumpur, MALAYSIA \\ Correspondence: Tariq Ahmed, department of Management Sciences, Balochistan university of information \\ technology, Engineering and Management Sciences, Quetta, Pakistan;
}

Received: February 11, 2017

Accepted: June 4, 2017

Online Published: June 12, 2017

doi:10.5430/bmr.v6n2p64

URL: https://doi.org/10.5430/bmr.v6n2p64

\begin{abstract}
This paper aims to identify the main difference on the major construct of the survey used to analyse the effect of contextual and environmental motivators and barriers on entrepreneurial intentions of universities graduates in Pakistan. The main objective was to observe the response of the survey respondents on the major construct of study. The results indicates that university graduates ranked high the importance of attitude towards entrepreneurship and perceived behaviour control in the process of venture creation. In addition, Perceived entrepreneurial motivators and barriers are also considered to be important in while staring some one's own business.
\end{abstract}

Keywords: Contextual and Environmental Motivators, business start-up

\section{Introduction}

From last few decades entrepreneurship is trusted has the driving force of economic development and the foreseeable future. Entrepreneurs are playing a constructive role in the development of main stream of economic development while creating thousands of new business and jobs (Mazzarol, Volery, Doss, \& Thein, 1999). Consequently, it can be globally observed that there is an increasing trend for government policy to advocate entrepreneurship. For example, in several studies the researches argued that many governments have accepted the financial economic theory of entrepreneurship (Jennings, Perren, \& Carter, 2005; Perren \& Jennings, 2005; Pittaway, 2005).

Acknowledging the importance of entrepreneurship, a great deal of research is devoted to explore the major determinants of entrepreneurship development. Earlier studies examined the importance and relationship of various factors with entrepreneurship. These includes personality taints (Bienkowska \& Klofsten, 2012; Collins \& Moore, 1970; Sexton \& Bowman, 1986; Shapero, 1975), characteristics of potential entrepreneurs and the firm-creation process (Krueger and Carsrud 1993; Reynolds, Hay, \& Camp, 1999; Liñán, 2004) the role of entrepreneurship education programs and trainings (Solomon \& Fernald, 1991, Vesper \& Gartner, 1997, Chrisman, 1997, Fayolle et al., 2006; Peterman \& Kennedy, 2003; Souitaris, Zerbinati, \& Al-Laham, 2007; Tkachev \& Kolvereid, 1999). However, in order to get a comprehensice picture of venture creation, several other environmental and contextual, such as legal, institutional and socioeconomic conditions, financial or nonfinancial assistance and other elements which depend on national or regional location (Gnyawali \& Fogel, 1994; Henrekson \& Davidsson, 2002) cannot be ignored in the process of developing entrepreneurial intentions. In order to clarify, the way in which, contextual and environmental factors are likely to act on entrepreneurial intentions and behaviour, we return to the fundamental tenet that entrepreneurial behaviour follows formation of entrepreneurial intentions (Bird, 1991) and the observation that the time between formation of entrepreneurial intentions and behaviour can be long (Lee and Wong, 2004). The contextual and environmental factors which may affect the formation of entrepreneurial intentions can also precipitate, facilitate or inhibit any behaviour that might follow from the formation of intention.

Therefore this explorative study attempted to explore the perception of university graduates enrolled in entrepreneurship education Pakistan on both individual characteristics and environmental and contextual factors (perceived entrepreneurial motivators and barriers). 


\section{Literature Review}

Several theories and models have been introduced in the entrepreneurship literature aiming to investigate the factors considered to be the foundation for the evaluation of entrepreneurial intentions and behaviors. However, the models which cultivate an understanding of the role of psychological variables in developing entrepreneurial intents are primarily guided by three models; (Shook, Priem, \& McGee, 2003): The Shapero (1982) model of the entrepreneurial event, the Ajzen (1987) theory of planned behaviour (TPB), and the Bird (1988) model of implementing entrepreneurial ideas. Among these models, the theory of planned behavior has acquired significant empirical support and is one of the most widely used psychological theories to explain intentions and predict human behavior (Kolvereid, 1996b).

\subsection{Entrepreneurial Intention and Behavior}

In the context of understanding the emergence of venture, intentions are considered a vital component in the whole process. Intentions are the best predictor of any planned behavior. Entrepreneurial behavior, such as staring one's own business, is intentional (Krueger \& Carsrud, 1993). In this particular framework, intentions can be explained as a mindset moderating an individual's attitude and behaviors towards recognizing a certain intention and developing approaches and methods to achieve it (Bird, 1988). The ability of intentions to predict behaviours means that understanding the formation of entrepreneurial intentions also provides an insight into the new venture initiation process. Previous empirical studies have supported this model, finding a positively significant relationship between entrepreneurial intention and behaviour (Kolvereid, 1996b).

\subsection{Attitude towards Entrepreneurial Intention}

In the domain of business start-ups and entrepreneurship, TPB proposes that three factors account for variations in entrepreneurial intention and can thus be used to predict intentions for entrepreneurial behaviour. These factors are: attitude towards entrepreneurial intention, subjective norms and perceived behaviour control.

There is general agreement the postulation that attitude towards an object is driven by beliefs about that object (Ajzen \& Fishbein, 1980). In addition, attitude towards entrepreneurship refers to the enticement of the proposed behavior or the degree to which an individual carries a positive or negative personal appraisement about being an entrepreneur (Ajzen, 1991, 2002; Kolvereid, 1996b). In this scenario, it could be argued that attitude towards behavior is an important element pertaining to the perception of desirability that considerably affects entrepreneurial intention. Furthermore, a positive attitude towards entrepreneurship leads to a positive entrepreneurial intention. Thus, a positive attitude towards entrepreneurship indeed reveals that an individual is more inclined to start his/her own business (Kolvereid, 1996a).

The second motivational factor and antecedent in TPB is subjective norms (SN). Subjective norms refers to the referral groups in society; certain subjective norms measure perceived social pressure from parents, colleagues, friends (Ajzen, 1991) to perform a particular behavior. Moreover, subjective norms refers to the opinion of "reference people", either they would appreciate or denigrate the decision to become an entrepreneur (Ajzen, 2001).

Perceived behavioral control (PBC) is another antecedent of TPB, which is argued to be an important element of behavioral intention. Among the three elements of TPB, perceived behavioral control is considered an important factor that significantly explains behavioral intentions. Perceived behavioral control, to some extent, is similar to but not exactly the same as the self-efficacy of (Bandura, 1977, 1982) and refers to the perceived ability of an individual to perform a particular behavior such as starting a business (Kolvereid, 1996a). Consideration of the PBC element in the process of new firm creation lies in its predictive capacity, since the prime argument of PBC in relation to the new firm creation process is how an individual efficiently and effectively utilizes his/her capabilities and abilities to better control behavior along the way (Ajzen, 2002). In this context, the following element could be influenced by different internal and external factors.

Thus, if individuals have substantial beliefs about their capabilities, and better control of initiating and executing the required activities for starting and establishing a business and also efficiently managing the events that affect their lives, this will lead to firm entrepreneurial intentions (Aijzen, 2002).

\subsection{The Impact of Contextual and Environmental Factors (Motivators and Barriers)}

The role of contextual and environmental factors, like legal, institutional and socioeconomic conditions, entrepreneurial and business skills, financial or nonfinancial assistance and other elements which depend on national or regional location (Gnyawali \& Fogel, 1994; Henrekson \& Davidsson, 2002) cannot be ignored in the process of developing entrepreneurial intention. Moreover, as (Pittaway \& Cope, 2007) and (Carayannis, Evans, \& Hanson, 
2003) point out, intentionality is surrounded by several compulsory aspects, such as cultural expectations, barriers to business start-ups and the environment, thus, intentionality itself would be more or less influenced by perceived and real barriers to action and would be affected by the general enterprise infrastructure. In addition, if contextual and environmental factors are similar to personality traits and play a role as essential facilitators of entrepreneurial activities (Hisrich \& Peters, 1995; Pennings, 1997), thus affecting the entrepreneurial decision process of entrepreneurs in their countries of origin, then it could be argued that these same be have an influencing effect on regulating attitude and also impact on their perceived behavioural control, entrepreneurial intention and behaviour (Watson, Hogarth-Scott, \& Wilson, 1998). Thus, contextual and environmental factors cannot be separated from physiological and demographical factors (Turker \& Selcuk, 2009) and this strongly suggests the need to consider not only temporal issues (Bird, 1991) but also the contextual and environmental factors which may precipitate, facilitate or inhibit entrepreneurial attitude, intentions and behaviour.

\section{Methodology}

\subsection{Procedures and Participants}

The data was collected from a population of final year university students enrolled in entrepreneurship education programs in Pakistan. Out of the 480 distributed survey questionnaires, we received 421 questionnaires, equivalent to an 87.7 per cent response rate. Upon scrutinizing the obtained data, only 317 useable survey questionnaires, equal to $72.5 \%$, were found to be effective and considered sufficient to carry out analysis. Table 1 shows a summary of the data collection and response rate to the survey.

\section{Results and Discussion}

\subsection{Descriptive Statistics}

We begin the statistical analysis with descriptive statistics as shown in Table 1. The composite constructs are included in the descriptive analysis. The results in Table 1 reveal the mean score and standard deviation of six major constructs in the study. It is evident from Table 4.1 that attitude towards entrepreneurship behaviour has a mean score of 4.73 with a standard deviation of 0.46 . The reported mean score implies that survey participants perceive attitude towards entrepreneurship behaviour to be one of the important factors in entrepreneurial behavioural intention. Table 1 further reports the mean and standard deviation scores of subjective norms (mean=3.18, $\mathrm{SD}=0.86$ ), perceived behaviour control (mean $=3.44, \mathrm{SD}=0.78$ ) and entrepreneurial intention (mean $=3.72, \mathrm{SD}=0.78$ ). Similarly, Table 1 indicates the mean score and standard deviation of perceived entrepreneurial motivators (mean $=3.93$, $\mathrm{SD}=0.28$ ) and perceived entrepreneurial barriers (mean $=3.59, \mathrm{SD}=0.34$ ).

Table 1. Descriptive Statistics

\begin{tabular}{llll}
\hline No & Variables & Mean Score & SD \\
\hline $\mathbf{1}$ & Attitude towards Behavior & 4.73 & 0.46 \\
$\mathbf{2}$ & Subjective Norms & 3.18 & 0.86 \\
$\mathbf{3}$ & Perceived Behavior Control & 3.44 & 0.78 \\
$\mathbf{4}$ & Entrepreneurial Intentions & 3.72 & 0.76 \\
$\mathbf{5}$ & Perceived Entrepreneurial Motivators & 3.93 & 0.28 \\
$\mathbf{6}$ & Perceived Entrepreneurial Barriers & 3.59 & 0.34 \\
\hline
\end{tabular}

4.2 Survey Results

The survey results draw on six key components of entrepreneurship theory and practices and contextual and environmental motivators and barriers. First, this survey reports graduate students perceived attitude towards the entrepreneurship. The graduate perceived attitude towards entrepreneurship leans on important economic and personal characteristics of the surveys subject. Such economic and personal characteristics of the graduates assist them in building their attitude and hence strong intentions towards business start-up. These economic and personal qualities of graduates include self-realization concerning the economic opportunities, unleashing their business potentials, embracing new challenges, low preference to be an employee, and having authority to make quick decisions. The results reported in the Table 2 suggest that, graduate students are largely inclined towards in starting their own business given the creative abilities, self-realization, fore-sighting the potentials in economic opportunities and are willing to accept challenges for venture creation. Comparatively, graduate students prefer more the power of making decisions and self-realization of their potentials for business start-up as compared to other key factor such as creativity, economic opportunity and tangible benefits of venture creation. 
Table 2. Students' scores on the scales of Attitude toward Entrepreneurship

\begin{tabular}{llll}
\hline Items & M & SD & V \\
\hline I would like to know about my abilities (self-realization) & 4.48 & 0.47 & 0.22 \\
I would like to make use of my creativity & 4.14 & 0.73 & 0.54 \\
I would to take the advantage of Economic opportunity & 4.18 & 0.67 & 0.45 \\
I would like a large share of my salary to be based on results & 4.08 & 0.63 & 0.40 \\
I would like to have a challenging job & 4.15 & 0.71 & 0.50 \\
I would like to have power in making my decisions & 4.61 & 0.46 & 0.22
\end{tabular}

Secondly, the survey of this study reports the response of subjective norms measure of the graduates. The graduates social norms is about perceived social pressure from family, friends and significnant others (Fishbein \& Ajzen, 2010). This point out to the perception of "reference people" may or may not motivate an individual to become entrepreneur. Although, the literature of entrepreneurship indicates a week contribution in the evolution of entrepreneurial intentions and to perform the entrepreneurial behaviour for individuals with strong locus of control, however, subjective norms is major determent of theory of planned behaviour and can be not be ignored in the process of examining and developing of entrepreneurial intentions. The results in Table 3 recommended that the participants of this survey are more concern to the perception of their family members and colleagues in starting their own business as compare to the perceptions of their friends.

Table 3. Students' scores on the scale of Subjective Norms N= (317)

\begin{tabular}{llll}
\hline Items & M & SD & V \\
\hline My closest family members think that I should pursue starting my own business & 3.45 & 0.96 & 0.92 \\
My closest friends think that I should pursue starting my own business & 3.1 & 1.15 & 1.33 \\
$\begin{array}{l}\text { My colleagues and people important to me think that I should pursue starting my own } \\
\text { business }\end{array}$ & 3.29 & 0.93 & 0.87 \\
\hline
\end{tabular}

Note: $M=$ (mean), $S D=$ standard deviation and $V=$ Variance

In the literature of entrepreneurship development, perceived behaviour control (PBC) in the process of venture creation receives a significant importance because of its high predictive capacity of entrepreneurial intentions. PBC refers to the perceived ease or difficulty of performing any particular belabour. In fact, perceived and actual personal inadequacies and external barriers interfere with the ability to perform a given behaviour and consequently with the perception of control that on has over the action and outcomes of the behaviour. The survey respondents (university graduates) were asked on perception of their ability and the impact of external factors in the business start-up. The results in Table 4 suggest that, the graduates are strongly believed on their ability to become entrepreneurs and sustain their business. However, the mean (3.51), in Table 4, which is more bend towards a response's scale of (to moderate extant), indicates uncertainty of graduates' control over the obstacle in the external environment.

Table 4. Students' scores on the scale Perceived behaviour control N= (317)

\begin{tabular}{llll}
\hline Items & M & SD & V \\
\hline It would be easy for me to become an entrepreneur & 3.46 & 0.98 & 0.96 \\
I believe that the number of events outside my control which could prevent me from being & 3.51 & 1.03 & 1.06 \\
self-employed is numerous & 4.05 & 0.71 & 0.51 \\
I am confident that I have the ability to successfully become entrepreneur & 3.70 & 0.98 & 0.96 \\
I am confident that if I start a business, the failure chances will be very low & &
\end{tabular}

Note: $M=$ (mean), $S D=$ standard deviation and $V=$ Variance

In past, several scholarly communications suggested that intentions have strong ability to predict behaviours. This study reports the response of entrepreneurial intentions of the graduates. Most of the items are direct question in nature. The perception of the graduates reported in Table 5 suggested these graduates are highly motivated and determinant to start their own business and live their life as an entrepreneur. 
Table 5. Students' scores on the scale Entrepreneurial intentions $N=(317)$

\begin{tabular}{llll}
\hline Items & M & SD & V \\
\hline My professional goal is to become an entrepreneur & 3.95 & 0.67 & .443 \\
I will make every effort to start and run my own firm & 4.04 & 0.68 & .466 \\
I am determined to create a firm in the future & 4.07 & 0.70 & .490 \\
I have very seriously thought of starting a firm & 3.96 & 0.70 & .487 \\
\hline
\end{tabular}

Note: $M=$ (mean), $S D=$ standard deviation and $V=$ Variance

This survey next presents the findings of entrepreneurial motivators by drawing upon three key parameters namely intrinsic rewards, extrinsic rewards and perceived entrepreneurial support. Since assessing the entrepreneurial motivation is considered a first step in business start-up, several individuals are take interest in business start-up as they see business ownership as an appealing career. In this survey, results suggest that changing him/herself, realizing a dream and, capitalize the inner potentials one have are considered key extrinsic rewards which pull these individuals to setup a venture.

Perceived entrepreneurial support is yet another crucial factor that adds to the perceived entrepreneurial motivation. Perceived motivational support is largely revolving around, how individuals see the positive image of entrepreneurs in the society. The positive image of entrepreneurs in the society is indeed appealing to business starters, though it is more in contextual in nature. The individuals surveyed in this research also suggest they degree of agreement towards to the availability of consultant and service support, which can help them in setting the start-up. In the South Asian context, these kinds of entrepreneurial motivators are of utmost important particular where entrepreneurship trainings and education are not imparted, and getting a reliable advice from the experts and the initial service thereon are much helpful in sustaining the ventures in the long run.

Next, the respondents of the survey rate creative atmosphere and entrepreneurial development initiatives within the educational institutions highly important that also play a pivotal role in perceived entrepreneurial motivators in providing new ideas for business start-ups. Survey respondents perceive a critical role of imparting entrepreneurial educations in motivating individuals for starting their own business, fostering entrepreneurial mindset, behaviour and skills which suggest more embedding of entrepreneurship strategy in educational institutes to uplift the entrepreneurial mindset. For such strategy, they perceive university-industry collaboration is an important factor.

The survey respondents conveyed variety of intrinsic factors that they considered as perceived entrepreneurial motivators. For instance, they feel that starting business let you get monetary compensation based on merit, provides you a comfortable retirement plan, personal saving, family circumstances, getting status out of being entrepreneur are indeed the tipping point which are appealing university graduates to start their own venture. Although it is difficult to established a pattern of relativity among these intrinsic motivators, statistically comfortable retirement plan, choice of location of the potential entrepreneur, follow someone a potential entrepreneur admire more are perceived more by the survey respondents as compared to other factors. 
Table 6. Students' scores on the scale Perceived Entrepreneurial Motivators (N-317)

\begin{tabular}{llll}
\hline Original Item & M & SD & V \\
\hline Extrinsic Reward & & & \\
To change your self & 3.29 & 1.51 & 2.28 \\
To realize your dream & 3.23 & 1.65 & 2.72 \\
To take advantage of your creative talents & 3.28 & 1.69 & 2.86 \\
\hline Perceived entrepreneurial support & & & \\
Entrepreneurs have a positive image in your society & 3.21 & 1.72 & 2.94 \\
Consultant and service support for new companies are available & 3.28 & 3.44 & 1.87 \\
The creative atmosphere in your university inspires you to develop ideas for new & 3.27 & 1.72 & 2.97 \\
businesses & & & \\
Entrepreneurial development institutes in Pakistan motivate you to start your own & 3.61 & 1.42 & 2 \\
business & 3.3 & 1.68 & 2.82 \\
The unnerving markets prompt you to start a business & & 1.48 & 2.19 \\
University and industry collaboration inspire you to develop ideas for new & 3.27 & & \\
businesses & & & \\
\hline Intrinsic Reward & 3.08 & 1.68 & 2.82 \\
To receive a salary based on merit & 3.21 & 1.47 & 2.15 \\
To provide a comfortable retirement & 3.36 & 1.55 & 2.4 \\
To work at a location of your choice & 3.08 & 1.53 & 2.33 \\
The need for a job & 2.97 & 1.52 & 2.32 \\
To invest your personal saving & 3.04 & 1.68 & 2.82 \\
To increase your status/prestige & 3.44 & 1.33 & 1.78 \\
To follow the example of a person you admire & 2.93 & 1.46 & 2.15 \\
To maintain a family tradition & & & \\
\hline Ne: & & & \\
\end{tabular}

Note: $M=$ (mean), $S D=$ standard deviation and $V=$ Variance

We next report the perceptions of potential graduate entrepreneurs on the legal and regulatory environment that is broadly categorized as external environmental factors in the entrepreneurship literature. The results suggest that, survey respondents convey bit of disappointment on the role of legal and environment. In particular, support of government agencies in assisting the new venture receives lowest average score. In addition, government assistance in sanctioning government contracts for new and small business also receive lows score, which serve important implication and area of concern of the new business entrepreneurs.

We next considered several other external environmental factors to gauge the perception of graduates. For instance, hard realities emerged in the literature is important environmental factor which encompasses bad economic factors, greater risk perceived after venture is established, and failure uncertainty. These three factors provide psychological strength or weakness to the potential business starter, and too that depends on how these three factors are considered during or before starting a venture. The perceptions conveyed by the survey respondents in this research suggest that, they are largely indifferent about these factors. Comparatively, they perceive risk involved in the venture as an important factor as compared bad economic condition and failure uncertainty. Similarly concerning the lack of resources, only sound marketing skills and finding a right partner to share a venture with the potential entrepreneur appeared to be major external environmental factors that are creating hindrance in their startups.

Next, in this survey we attempted to explore the notion of the graduates on complaint cost, this factor is considered an important element in the process of evaluation entrepreneurship. Since compliment cost is encircle the factors which are indeed highly related with venture creation both at the initial level and for sustaining of successful business. These include, obedience of the regulations, taxes and fee and labour. They survey respondents moderately reported the importance of the taxes and labour in the process of venture creation. 
Beside other major environmental barriers the graduates were also asked on their perception about other complementary factors of venture creation. The graduates reported uncertainly on the success of business and also anxiety on strength and potential of business idea. Comparatively they perceive the social support as an important factor in the process of venture creation.

Finally, we ask the survey respondents on financing of business, which in fact is considered among the most important factor in the saturating someone's business. The graduates of this ranked high the unavailability of financial support from the family and friends as compare to their own saving and obtaining finance from other sources. Generally, financial support from the immediate family is considered to be the important factor in the process of venture creation.

Table 7. Students' scores on the scale Perceived Entrepreneurial Motivators (N-317)

\begin{tabular}{llll}
\hline Items & M & SD & V \\
\hline Legal and Regulatory Environment & & & \\
Government organizations do not assist individuals starting their own businesses & 3.15 & 1.60 & 2.55 \\
Government supports government contracts for new and small businesses & 2.86 & 1.51 & 2.27 \\
Local and national government have no special support for individuals starting a new & 3.30 & 1.39 & 1.94 \\
business & 3.25 & 1.33 & 1.78 \\
Government does not sponsor organizations that help new businesses develop & 3.25 \\
\hline
\end{tabular}

\section{Hard reality}

Bad economic factors

$\begin{array}{lll}3.42 & 1.23 \quad 1.50\end{array}$

Risk greater than initially expected

$\begin{array}{lll}3.65 & 1.17 \quad 1.36\end{array}$

The uncertainty of failure

$3.18 \quad 1.56 \quad 2.43$

\section{Lack of skills or resources}

Lack of marketing skills

Lack of managerial or financial expertise

Lack of info about business start-ups

Finding the right partner

\section{Complaint cost}

Compliance with government regulations

High taxes and fees

Finding suitable labour

\section{Lack of support}

Fear of failure

Convincing others it is a good idea

No one wants to help you

Lack of suitable premises

\section{Lack of capital}

Difficulty in obtaining finance

$\begin{array}{lll}3.18 & 1.54 & 2.36\end{array}$

2.55

1.56

2.43

2.80

3.12

$\begin{array}{ll}1.48 & 2.20\end{array}$

Lack of own savings or assets $3.15 \quad 1.33$

3.38

1.19

1.41

3.38

$\begin{array}{ll}1.44 & 2.07\end{array}$

Lack of support from family or friend

Note: $M=$ (mean), $S D=$ standard deviation and $V=$ Variance

\section{Conclusion}

Using data from a sample of university graduates enrolled in entrepreneurship education programs, this article has attempted to determine the key factors of entrepreneurial attitude and environmental and contextual motivators and barriers to venture creation. 
It appears that the university graduates considered attitude towards entrepreneurship and perceived behaviour control on be the most important factors as compare to subjective norms in the evolution of entrepreneurial intentions. Generally they observed to be more inclined to work independently and obtain rewards based on their efforts and work. Further they believe perceive behaviour control is a factor that may cause someone to pursue a business career while having a strong control on their behaviour or hinder from starting their business in the presence of fear of failure.

Further it appears that for university graduates, to-be entrepreneurs are predominantly equally motivated by the sub motivators; intrinsic rewards, extrinsic rewards and perceived entrepreneurial support. It indicates that these perceived entrepreneurial motivators act as push factors, which are well documented in previous studies, in urging individuals, to pursue their entrepreneurial career, those working within a risk adverse work environment and caused by the frustration with previous employment.

Finally, we attempted to explore the perception of graduates on perceived environmental and contextual barriers, It appears that the factors such as heard reality, complaint cost, lack of financing and lack of financial financial support from family, causes a certain fear of failure and hinder individual from pursuing their entrepreneurial career. Poor economic conditions have been reported in several studies as a strong contributor to the creation of start-ups.

\section{References}

Aijzen, I. (2002). Perceived behavioural control, self-efficacy, locus of control and the theory of planned behaviour. Journal of applied social psychology, 32, 665-683. https://doi.org/10.1111/j.1559-1816.2002.tb00236.x

Ajzen, I. (1991). The theory of planned behavior. Organizational behavior and human decision processes, 50(2), 179-211. https://doi.org/10.1016/0749-5978(91)90020-T

Ajzen, Icek. (1988). Attitudes and personality traits. Attitudes, Personality and Behavior, 1-24.

Ajzen, I., \& Fishbein, M. (1980). Understanding attitudes and predicting social behaviour.

Bandura, A. (1977). Self-efficacy: toward a unifying theory of behavioral change. Psychological review, 84(2), 191. https://doi.org/10.1037/0033-295X.84.2.191

Bandura, A. (1982). Self-efficacy mechanism in human agency. American psychologist, 37(2), 122. https://doi.org/10.1037/0003-066X.37.2.122

Bienkowska, Dzamila, \& Klofsten, Magnus (2012). Creating entrepreneurial networks: Academic entrepreneurship, mobility and collaboration during $\mathrm{PhD}$ education. Higher Education, 64(2), 207-222. https://doi.org/10.1007/s10734-011-9488-x

Bird, B. (1988). Implementing entrepreneurial ideas: The case for intention. Academy of management review, 13(3), $442-453$.

Carayannis, E. G., Evans, D., \& Hanson, M. (2003). A cross-cultural learning strategy for entrepreneurship education: outline of key concepts and lessons learned from a comparative study of entrepreneurship students in France and the US. Technovation, 23(9), 757-771. https://doi.org/10.1016/S0166-4972(02)00030-5

Chrisman, James J. (1997). Program evaluation and the venture development program at the University of Calgary: a research note. Entrepreneurship Theory and Practice, 22, 59-74.

Collins, Orvis, \& Moore, David G. (1970). The organization makers. New York: Appleton

Fayolle, Alain, Gailly, Benoît, \& Lassas-Clerc, Narjisse. (2006). Assessing the impact of entrepreneurship education programmes: a new methodology. Journal of European Industrial Training, 30(9), 701-720. https://doi.org/10.1108/03090590610715022

Gnyawali, Devi R, \& Fogel, Daniel S. (1994). Environments for entrepreneurship development: key dimensions and research implications. Entrepreneurship Theory and Practice, 18, 43-43.

Henrekson, Magnus, \& Davidsson, Per. (2002). Determinants of the Prevalence of Start-Ups and High-Growth Firms. Small Business Economics, 19(2).

Jennings, P. L., Perren, L., \& Carter, S. (2005). Guest editors' introduction: Alternative perspectives on entrepreneurship research. Entrepreneurship theory and practice, 29(2), 145-152. https://doi.org/10.1111/j.1540-6520.2005.00073.x

Kolvereid, L. (1996a). Organizational employment versus self-employment: reasons for career choice intentions. Entrepreneurship theory and practice, 20, 23-32. 
Kolvereid, L., (1996b). Prediction of employment status choice intentions. Entrepreneurship Theory and Practice. 21(1), 47-57

Krueger, N. F., \& Carsrud, A. L. (1993). Entrepreneurial intentions: applying the theory of planned behaviour. Entrepreneurship \& Regional Development, 5(4), 315-330. https://doi.org/10.1080/08985629300000020

Lee, Soo Hoon, \& Wong, Poh Kam. (2004). An exploratory study of technopreneurial intentions: A career anchor perspective. Journal of Business Venturing, 19(1), 7-28. https://doi.org/10.1016/S0883-9026(02)00112-X

Liñán, F. (2004). Intention-based models of entrepreneurship education. Piccolla Impresa/Small Business, 3(1), 11-35.

Mazzarol, T., Volery, T., Doss, N., \& Thein, V. (1999). Factors influencing small business start-ups: a comparison with previous research. International Journal of Entrepreneurial Behaviour \& Research, 5(2), 48-63. https://doi.org/10.1108/13552559910274499

Pennings, J. and Kimberly, J. (1997). Environmental influences on the creation process. 135-160.

Perren, L., \& Jennings, P. L. (2005). Government discourses on entrepreneurship: issues of legitimization, subjugation, and power. Entrepreneurship theory and practice, 29(2), 173-184. https://doi.org/10.1111/j.1540-6520.2005.00075.x

Peterman, N. E., \& Kennedy, J. (2003). Enterprise education: Influencing students' perceptions of entrepreneurship. Entrepreneurship-Theory and Practice, 28(2), 129-144. https://doi.org/10.1046/j.1540-6520.2003.00035.x

Pittaway, L. (2005). Philosophies in entrepreneurship: a focus on economic theories. International Journal of Entrepreneurial Behavior \& Research, 11(3), 201-221. https://doi.org/10.1108/13552550510598790

Pittaway, L., \& Cope, J. (2007). Entrepreneurship Education A Systematic Review of the Evidence. International small business journal, 25(5), 479-510. https://doi.org/10.1177/0266242607080656

Reynolds, P. D., Hay, M., \& Camp, S. M. (1999). Global entrepreneurship monitor. Kansas City, Missouri: Kauffman Center for Entrepreneurial Leadership.

Sexton, Donald L, \& Bowman, Nancy B. (1986). Validation of a personality index: Comparative psychological characteristics analysis of female entrepreneurs, managers, entrepreneurship students and business students. Frontiers of Entrepreneurship Research, 40-51.

Shapero, Albert. (1975). The displaced, uncomfortable entrepreneur. Psychology Today 9(6):83-88.

Shapero A. 1982. Social Dimensions of Entrepreneurship. In C. Kent, D. Sexton and K. Vesper, eds, The Encyclopedia of Entrepreneurship. Englewood Cliffs: Prentice-Hall, 72-90

Shook, C. L., Priem, R. L., \& McGee, J. E. (2003). Venture creation and the enterprising individual: a review and synthesis. Journal of management, 29(3), 379-399. https://doi.org/10.1016/S0149-2063(03)00016-3

Solomon, George T, \& Fernald Jr, Lloyd W. (1991). Trends in small business management and entrepreneurship education in the United States. Entrepreneurship Theory and Practice, 15(3), 25-39.

Souitaris, Vangelis, Zerbinati, Stefania, \& Al-Laham, Andreas. (2007). Do entrepreneurship programmes raise entrepreneurial intention of science and engineering students? The effect of learning, inspiration and resources. Journal of Business Venturing, 22(4), 566-591. https://doi.org/10.1016/j.jbusvent.2006.05.002

Tkachev, Alexei, \& Kolvereid, Lars. (1999). Self-employment intentions among Russian students. Entrepreneurship \& Regional Development, 11(3), 269-280. https://doi.org/10.1080/089856299283209

Turker, D., \& Selcuk, S. S. (2009). Which factors affect entrepreneurial intention of university students? Journal of European Industrial Training, 33(2), 142-159. https://doi.org/10.1108/03090590910939049

Vesper, K. H., \& Gartner, W. B. (1997). Measuring progress in entrepreneurship education. Journal of Business Venturing, 12(5), 403-421. https://doi.org/10.1016/S0883-9026(97)00009-8

Watson, K., Hogarth-Scott, S., \& Wilson, N. (1998). Small business start-ups: success factors and support implications. International Journal of Entrepreneurial Behaviour \& Research, 4(3), 217-238. https://doi.org/10.1108/13552559810235510 